
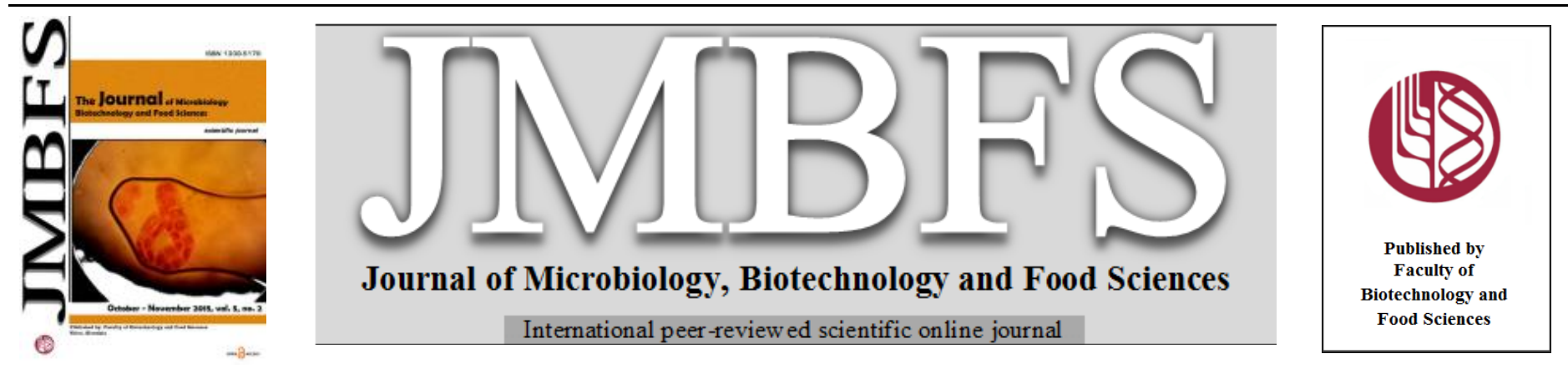

\title{
ISOLATION AND CHARACTERIZATION OF YEAST FROM ANTHOCYANIN RICH TROPICAL FRUITS AS WINE STARTER CULTURE
}

\section{Chetan Arekar and S. S. Lele*}

\section{$\operatorname{Address}(e s)$ :}

Institute of Chemical Technology, Department of Food Engineering \& Technology, Matunga,-400019, Mumbai, Maharashtra, India.

*Corresponding author: ss.lele@ictmumbai.edu.in

doi: 10.15414/jmbfs.2015.5.2.146-154

\section{ARTICLE INFO}

Received 24. 2. 2015

Revised 4. 6. 2015

Accepted 5. 7. 2015

Published 1. 10. 2015

Regular article

OPEN $\partial_{\text {ACCESS }}$

\begin{abstract}
Tropical fruit wines are gaining importance for its health benefits. However, the potential is unexplored in India and this work of isolation of indigenous yeast strains from the tropical fruit was undertaken. 28 strains of yeasts were isolated from tropical fruits, Syzygium cumini (Linn.) Skeel (Jamun) and Garcinia indica (Choisy) (Kokum) on a selective medium. The screening parameters were glucose and ethanol tolerance. Three most glucose and ethanol tolerant cultures were selected by testing tolerance for glucose (10-25\% $\mathrm{w} / \mathrm{v})$ and ethanol $(6-15 \% \mathrm{v} / \mathrm{v})$. Further characterization of these 3 cultures was carried out using biochemical and molecular test by sequencing internal transcribed spacer (ITS) region. Infer molecular phylogeny established that the three isolates viz, FJ 10, JR 01 and KF 01 were Saccharomyces sp. FJ 10, Candida tropicalis JR 01, Saccharomyces sp. KF 01 respectively. Till date to the best of our knowledge we are the first to report the isolation of tolerant Saccharomyces species from Jamun and Kokum fruits. Further studies on fruit wine production from the selected isolates showed promising results.
\end{abstract}

Keywords: Jamun, Kokum, yeast isolation, internal transcribed spacer

\section{INTRODUCTION}

Yeasts are ubiquitous in nature and indispensable in manufacture of alcoholic beverages, distilleries and in baking industry (Ligras et al., 2007). Current research trend emphasizes mainly upon isolation and characterization of yeast strain which are tolerant to both sugar and ethanol concentration. Ethanol tolerance has been also studied by genetic modification of yeast. Kyung Man You et al., (2002) have altered OLE1 desaturase gene responsible for unsaturated fatty acid composition of yeast cell membranewithacyl-CoA desaturase from other sources. Isolation of wild yeast strains belonging to genera Saccharomyces, Debaryamyces, Kodamaea, Sporobolomyces, Candida, Pichia, Rhodotorula, Crptococcusetc from rotten fruit or fruit rind have been attempted by various researchers and is depicted in the Table 1 given below. Other than fruits, yeast isolation is also reported from flowers, insects (feed on flower and fruits), grains, leaves, tree sap, dung and soil (Spencer \& Spencer, 1997).

Table 1 Different native yeast species from fruits and their sugar and ethanol tolerance

\begin{tabular}{|c|c|c|c|c|}
\hline Source & $\begin{array}{c}\text { Sugar } \\
\text { tolerance } \\
(\% \mathrm{w} / \mathrm{v})\end{array}$ & $\begin{array}{l}\text { Ethanol } \\
\text { tolerance } \\
(\% \mathrm{v} / \mathrm{v})\end{array}$ & Yeast species identified & References \\
\hline Tamarind & 20 & 14 & Saccharomyces cerevisiae & \multirow{7}{*}{ Ali et al.,(2014) } \\
\hline Yoghurt & 20 & 14 & Saccharomyces cerevisiae & \\
\hline Kanji & 15 & 12 & Saccharomyces cerevisiae & \\
\hline Soil Vineyard & 10 & 8 & Saccharomyces rosinii & \\
\hline Soil Sugarcane & 10 & 8 & Saccharomyces rosinii & \\
\hline Kanji & 10 & 10 & Saccharomyces exiguous & \\
\hline Soil Fruit market & 10 & 9 & Rhodotorulaminuta & \\
\hline Kiwi & 30 & 10 & Saccharomyces cerevisiae & Lee et al.,(2011) \\
\hline Grape & - & 12 & Saccharomyces cerevisiae & Chiranjeevi et al.,(2013) \\
\hline Papaya & 45 & 12 & Saccharomyces cerevisiae & \multirow{7}{*}{ C. Maragatham et al.,(2011 } \\
\hline Papaya & 40 & 8 & Saccharomyces bayanus & \\
\hline Papaya & 40 & 8 & Saccharomyces uvarum & \\
\hline Papaya & 45 & 10 & Saccharomyces italicus & \\
\hline Papaya & 45 & 10 & Saccharomyces pasteurianus & \\
\hline Papaya & 40 & 8 & Saccharomyces pombe & \\
\hline Papaya & 45 & 10 & Zygosaccharomyces $s p$ & \\
\hline Cashew apple & 15 & 12 & Saccharomyces cerevisiae & \multirow{4}{*}{ Osho A.,(2005) } \\
\hline Cashew apple & 20 & 11 & Saccharomyces cerevisiae & \\
\hline Cashew apple & 15 & 10 & Saccharomyces cerevisiae & \\
\hline Cashew apple & 10 & 9 & Saccharomyces uvarum & \\
\hline Grape & NR & NR & Hanseniaspora uvarum & \multirow{4}{*}{ J.M.Clemente-Jimenez et al.,(2004) } \\
\hline Grape & NR & NR & Candida stellate & \\
\hline Grape & NR & NR & Issatchenkia orientalis & \\
\hline Grape & NR & NR & Issatchenkia terricola & \\
\hline
\end{tabular}




\begin{tabular}{|c|c|c|c|c|}
\hline Grape & $\mathrm{NR}$ & NR & Metschnikowia pulcherrima & \multirow{7}{*}{ Ebabhi et al.,(2013) } \\
\hline Grape & NR & NR & Pichiafermentans & \\
\hline Grape & NR & NR & Saccharomyces cerevisiae & \\
\hline Kola nuts & NR & NR & Candida tropicalis & \\
\hline Cassava & NR & NR & Kluyveromyces marxianus & \\
\hline Maize & NR & NR & Pichiacaribbica & \\
\hline Sorghum & NR & NR & Saccharomyces cerevisiae & \\
\hline Grape & NR & NR & Aureobasidium pullulans & \multirow{8}{*}{ Yun sun et al.,(2014) } \\
\hline Grape & NR & NR & Candida zemplinina & \\
\hline Grape & NR & NR & Hanseniaspora uvarum & \\
\hline Grape & NR & NR & Hanseniaspora occidentalis & \\
\hline Grape & NR & NR & Issatchenkia terricola & \\
\hline Grape & NR & NR & Metschnikowia pulcherrima & \\
\hline Grape & NR & NR & Pichiakluyveri & \\
\hline Grape & NR & NR & Saccharomyces cerevisiae & \\
\hline Grape & NR & NR & Candida azyma & \multirow{6}{*}{ P. Chavan et al.,(2009) } \\
\hline Grape & NR & NR & Candida quercitrusa & \\
\hline Grape & NR & NR & Debaryomyce shansenii & \\
\hline Grape & NR & NR & Hanseniaspora guilliermondii & \\
\hline Grape & NR & NR & Hanseniaspora viniae & \\
\hline Grape & NR & NR & Sacharomyces cerevisiae & \\
\hline Grape & NR & NR & Sacharomyces cerevisiae & E. Nikolaou et al.,(2006) \\
\hline
\end{tabular}

Although tropical fruits are abundant in several essential bioactive compounds and are mainstay in Indian traditional medicinal system, Ayurveda but still remain underutilized. Some of the tropical fruits with their bioactive compounds have been mentioned in Table 2 .

Table 2 Tropical fruits, their bioactive compounds and medicinal property.

\begin{tabular}{|c|c|c|c|c|}
\hline Scintific name & $\begin{array}{c}\text { Common } \\
\text { name }\end{array}$ & Bioactive compounds & Medicinal property & Reference \\
\hline Syzygium cumini & Jamun & $\begin{array}{l}\text { Jamboline, mycaminose,3,6-hexa } \\
\text { hydroxyl diphenoyl glucose, 4,6- } \\
\text { hexahydroxy diphenoyl glucose, ellagic } \\
\text { acid, gallic acid, tannins, Quercetin, } \\
\text { Oleanolic acid, Kaempferol, Myricetin, } \\
\text { Betulinic acid, Delphinidin, Petunidin, } \\
\text { Malvidin, etc }\end{array}$ & $\begin{array}{l}\text { Anti-inflammatory, } \\
\text { Antioxidant, anti- } \\
\text { diabetic, antibacterial, } \\
\text { anti-diarrheal, } \\
\text { antineoplastic, } \\
\text { radioprotective }\end{array}$ & $\begin{array}{l}\text { Shrikant et al., (2012) } \\
\text { Muruganandan S. et al., } \\
(2001), \text { Brito } \text { et al., (2007), } \\
\text { Ruan } \text { et al., (2008), Sridhar et } \\
\text { al., (2005), Y. Zhao et al., } \\
(2009), \text { V. Benkovic et al., } \\
(2008), \text { A. Kumar } \text { et al., } \\
(2008)\end{array}$ \\
\hline Garcinia indica & Kokum & $\begin{array}{l}\text { Garcinol, Hydroxy citric acid, cyanidine- } \\
\text { 3-glucoside, cyanidine-3-sambubioside, } \\
\text { xanthochymol, etc }\end{array}$ & $\begin{array}{l}\text { Antibacterial, free radical } \\
\text { scavenging activity, anti- } \\
\text { obesity, gastroprotective, } \\
\text { antidiabetic, } \\
\text { cardioprotective, } \\
\text { antineoplastic, } \\
\text { antioxidant }\end{array}$ & $\begin{array}{l}\text { Varalakshmi et al (2010), Alia } \\
\text { et al., (2008), Jena et al., } \\
(2002), \text { Chatterjee } \text { et al., } \\
(2003), \text { Kirana and Srinivasan } \\
(2010), \text { Xu } \text { et al (2004), Selvi } \\
\text { et al, (2003) }\end{array}$ \\
\hline Carica papaya & Papaya & $\begin{array}{l}\text { Lycopene, } \beta \text {-criptoxhantin, } \beta \text {-carotene, } \\
\text { Caffeic acid, ferulic acid, myricetin, } \\
\text { quercetin, , isorhamnetin, kaempferoletc }\end{array}$ & $\begin{array}{l}\text { Antioxidant, anti- } \\
\text { diarrheal, digestive, } \\
\text { sedative, diuretic, anti- } \\
\text { obesity, abortifacient, } \\
\text { anti-microbial, anti- } \\
\text { malerial }\end{array}$ & $\begin{array}{l}\text { Rivera-Pastranaet al., (2010), } \\
\text { Krishna et al., (2008) }\end{array}$ \\
\hline Ananas comosus & Pineapple & $\begin{array}{l}\text { Bromelain, } \alpha \text {-carotene, } \beta \text {-carotene, } \beta \text { - } \\
\text { cryptoxanthin, lutein, lycopene, } \\
\text { neoxanthin, violaxanthin, zeaxanthin etc. }\end{array}$ & $\begin{array}{l}\text { antiscorbutic, cholagogic, } \\
\text { diaphoretic,anti- } \\
\text { inflammatory, antioxidant }\end{array}$ & $\begin{array}{l}\text { M.Kalaiselvi et al., (2012), } \\
\text { Monzon R. B. et al, (1995), } \\
\text { Kongsuwan A et al., (20098), } \\
\text { Freitas A et al., (2014) }\end{array}$ \\
\hline Musa acuminata & Banana & $\begin{array}{l}\text { Prodelphinidins, flavonol glycosides, } \\
\text { procyanidin, flavan-3-ols, Norepinephrine, } \\
\text { dopamine, serotoninetc }\end{array}$ & $\begin{array}{l}\text { Antioxidant, } \\
\text { antimicrobial, anti- } \\
\text { diarrheal, digestive, anti- } \\
\text { diabetic, anti cancer, } \\
\text { cardioprotective }\end{array}$ & $\begin{array}{l}\text { Rebello et al., (2014), } \\
\text { Fagbemi et al., (2009), K. P. } \\
\text { Sampath Kumar et al., (2012) }\end{array}$ \\
\hline $\begin{array}{l}\text { Artocarpus } \\
\text { heterophyllus }\end{array}$ & Jackfruit & $\begin{array}{l}\text { Catechin, ascorbic acid, chlorogenic acids, } \\
\text { morin, dihydromorin, cynomacurin, } \\
\text { artocarpin, isoartocarpin, cyloartocarpin, } \\
\text { artocarpesin, oxydihydroartocarpesin, } \\
\text { artocarpetin, norartocarpetin, } \\
\text { cycloartinone, betulinic acid, } \\
\text { artocarpanone, heterophylol etc. }\end{array}$ & $\begin{array}{l}\text { Antioxidant, anti- } \\
\text { diabetic, anti- } \\
\text { inflammatory, } \\
\text { immunomodulatory, } \\
\text { antibacterial }\end{array}$ & $\begin{array}{l}\text { Sharma A et al., (2013), } \\
\text { Prakash et al., (2009) }\end{array}$ \\
\hline Mangifera indica & Mango & $\begin{array}{l}\text { Mangiferin, Ascorbic acid, Quercetin, } \\
\text { Kaempferol, Gallotannins, Ellagic acid, } \\
\text { Rhamnetin 3-0 galactoside, Isomangiferin, } \\
\text { Gallic acid, Tannin, Coumarin, Caffeic } \\
\text { acid, Vanillin, Ferulic acid, Cinamic acid, } \\
\text { cyanidin 3-O-galactoside, peonidin 3-O- } \\
\text { galactoside, rhamnetin 3-O-â- } \\
\text { galactopyranoside, rhamnetin 3-O-â- } \\
\text { glucopyranoside etc. }\end{array}$ & $\begin{array}{l}\text { Antioxidant, } \\
\text { cardioprotective, } \\
\text { antidiabetic, anti-viral, } \\
\text { hypotensive, anti- } \\
\text { inflammatory, anti } \\
\text { parasitic, anti tumor, anti } \\
\text { HIV, gastroprotective, } \\
\text { hypolipidemic }\end{array}$ & $\begin{array}{l}\text { Berardini et al (2005), Li et al } \\
\text { (2014). Nicolai Berardin et al } \\
(2005), \text { K. A. Shah et al, } \\
(2010)\end{array}$ \\
\hline
\end{tabular}


The selected tropical fruits Syzygium cumini (Linn.) Skeel Syn Syzygium jambolanum, Eugenia cumini and Garcinia indica (Choisy) Syn Brindonia indica belonging to Myrtaceae and Guttiferae family respectively. Both these fruits contain several bioactive compounds (Table 2). Percentage of Anthocyanin's in these two fruits is significantly high and hence has a huge potential in manufacture of coloured fermented beverages.

These fruits are processed at small and medium scale in unorganized sector to make beverages, preserves and concentrates. The bioactives could be made available if the preservation is by fermentation since there will be minimum thermal degradation. Tropical fruit wines are becoming popular and could be a good value addition to these fruits which are not cultivated but wildly grown. Micropropagation of these tropical fruit plants is not developed as these plants are grown naturally in forest. We observed that there is slow fermentation in Jamun and kokum fruit juices. These fruit juices have very low $\mathrm{pH}$ and have antibacterial activity too (Shrikant et al., 2012 and Varalakshmi et al., 2010). The fermentation of fruit juices may be carried out by natural yeast flora. The fermented beverages developed by natural yeast may be beneficial for diabetic and obese people as these two diseases states are interlinked. Such fermented beverages may have very low sugar and slight alcohol content.

The main objective of this study is to evaluate indigenous yeast strains as a wine starter culture based on their glucose tolerance, ethanol tolerance and alcohol production ability.

\section{MATERIALS AND METHODS}

\section{Materials}

Sugar dics, Sabouraud Chloramphenicol agar, yeast extract-peptone-dextrose (YPD) agar medium, dextrose, Sodium chloride, yeast extract, potassium chloride, monopotassium phosphate, manganese sulphate, magnesium sulphate, glycerol, ferric chloride, calcium chloride, sodium hydroxide and Phenol, chloroform, ethyl alcohol, bromocresol green were procured from Himedia laboratories, India and Merck Millipore, India respectively. 2,2-diphenyl-1picrylhydrazyl (DPPH) was procured from Sigma Chemicals.

\section{Isolation of yeast}

Tropical fruits Jamun and Kokum were provided as a kind gift by Dr. Hedgewar Smruti Seva Prakalpa, Sawantwadi, Maharashtra. Microbial samples were taken from rind of fruits and rotten fruits. Isolates were grown on Sabouraud Chloramphenicol agar for selective cultivation of yeast at $30^{\circ} \mathrm{C}$ for $48 \mathrm{hrs}$. Yeast like colonies were further streaked onto fresh Sabouraud Chloramphenicol agar. For further differentiation among isolates with same colony characters were grown in Wallerstein Laboratory Nutrient (WLN) agar. Morphologically distinguished colonies were selected \& gram nature was observed under microscope at 100X magnification. Pure culture was maintained on yeast extractpeptone-dextrose (YPD) agar medium. Glycerol stocks of the isolates were prepared and stored at $-20^{\circ} \mathrm{C}$ for future use. Cultures were revived by inoculating them in YPD broth at $30^{\circ} \mathrm{C}, 200 \mathrm{rpm}$ for $72 \mathrm{hrs}$.

\section{Screening for ethanol tolerance}

Ethanol tolerance of the isolates was evaluated by growing the isolates separately in sterilized YPD broth containing varying concentration of ethanol from 6 $15 \% \mathrm{v} / \mathrm{v}$. The isolates were then incubated at $30^{\circ} \mathrm{C}$ for $72 \mathrm{hrs}$ at $200 \mathrm{rpm}$ in an orbital incubator shaker (Orbitek). Growth of the isolates was monitored up to 72 hrs using spectrophotometer and taking the optical density at $660 \mathrm{~nm}$ after every $6 \mathrm{hrs}$ using UV-visible spectrophotometer (Shimadzu 1800). The experiment was performed in triplicates.

\section{Screening for Sugar tolerance of ethanol tolerant isolates}

Ethanol tolerant yeast cultures were then evaluated for its sugar tolerance. The isolates were inoculated in Yeast extract-peptone broth containing varying concentration of dextrose $(10 \%, 15 \%, 20 \% \& 25 \%)$ and incubated at $30^{\circ} \mathrm{C}$ for 72 hrs at $200 \mathrm{rpm}$. Growth was monitored by recording the turbidity of the flasks at $660 \mathrm{~nm}$ using UV-visible spectrophotometer (Shimadzu 1800). The experiment was performed in triplicates

\section{Identification \& molecular characterization of ethanol-sugar tolerant isolates}

Standard routine tests were followed for the morphological and biochemical characterization of the isolates (Bernette et al., 2000; Kurtzman \& Fell, 1998). Basal media mentioned by Bernette et al., (2000) was used for carbon and nitrogen assimilation/fermentation tests. Isolates were observed for fermentation (gas production in durhams tubes) and assimilation (growth). Genetic characterization was performed in accordance with the methods reported by White et al., 1990. Active, vegetative biomass of the isolates was harvested by centrifugation at $10000 \mathrm{rpm}, 10^{\circ} \mathrm{C}$ for $15 \mathrm{~min}$. Phenol-chloroform method was used for genomic DNA isolation. ITS region was amplified by PCR using ITS primers-ITS 1 (5'-TCCGTAGGTGAACCTGCGG-3'), ITS 2 (5', GCTGCGTTCTTCATCGATGC-3'), ITS 4 TCCTCCGCTTATTGATATGC-3') (White et al., 1990). PCR product was further sequenced in $\mathrm{ABI} 3730 \mathrm{XL}$ sequencing machine. The sequences were analyzed with "Type strains" from NCBI nucleotide database.

\section{Phylogenetic analysis}

The evolutionary history was inferred using the Neighbor-Joining method (Saitou and Nei, 1987). The percentage of replicate trees in which the associated taxa clustered together in the bootstrap test (1000 replicates) is shown next to the branches. The tree was drawn to scale, with branch lengths in the same units as those of the evolutionary distances used to infer the phylogenetic tree. The evolutionary distances were then computed using the Kimura 2-parameter method (Kimura, 1980) and were in the units of the number of base substitutions per site. The rate variation among sites was modelled with a gamma distribution (shape parameter $=1$ ). All positions containing gaps and missing data were eliminated. Evolutionary analyses were conducted in MEGA5 (Tamura, 2007).

\section{Microvinification}

Jamun fruit was used for microvinification studies with selected yeast isolates including standard yeast, S. cerevisiae NCIM 3215. $75 \mathrm{ppm}$ potassium metabisulphate was added to the must before fermentation. The must was inoculated yeast isolates FJ 10, KF 01 and NCIM 3215 separately in duplicate. Fermentation was carried out at $28 \pm 1^{\circ} \mathrm{C}$ for 5 days in specially designed fermentation assembly. Fermentation process was observed on the basis of total soluble solids ( ${ }^{\circ}$ brix). Fermentation must were centrifuged at $5000 \mathrm{rpm}, 4^{\circ} \mathrm{C}$ and filtered through $1 \mu \mathrm{m}$ filter using vacuum. Wine was kept at $4^{\circ} \mathrm{C}$ till analysis.

Titratable acidity of the wine and must was estimated as per AOAC, 2000 protocol. Residual sugars were estimated by Dinitrosalicylic Acid reagent method (Miller Gail Lorenz., 1959). Total Anthocyanin's were estimated by $\mathrm{pH}$ differentiation method as described by Lee et.al.,(2005). Per cent free radical scavenging activity of wine was estimated by using the 2,2-diphenyl-1picrylhydrazyl (DPPH) assay (Abe et al.,1998).

\section{Gas Chromatography}

Alcohols were analysed by direct injection of $0.5 \mu \mathrm{l}$ of sample into Agilent $7820 \mathrm{~A}$ gas chromatograph with flame ionization detector $\left(230^{\circ} \mathrm{C}\right)$ and a Porapack Q column (6 ft., mesh size 80/100, 1/8 in. OD, $2 \mathrm{~mm} \mathrm{ID)}$ ). The carrier gases were nitrogen and hydrogen at a flow rate of $25 \mathrm{ml} / \mathrm{min}$ and $50 \mathrm{ml} / \mathrm{min}$ respectively. The split ratio was $1: 10$ with air flow $300 \mathrm{ml} / \mathrm{min}$. The standard with different concentration and sample were injected with isopropyl alcohol as an internal standard. Analysis was done in triplicates.

\section{RESULTS AND DISCUSSION}

\section{Isolation of Yeast}

Tropical fruits viz, Kokum and Jamun are abundant in the anthocyanin content which makes them suitable substrate for isolation of yeast for colored fermented beverages production. Fruit rind and pulp of decayed Jamun and Kokum was used as a source for yeast isolation. Microbial suspension was prepared in sterilized saline and inoculated onto selective medium, Sabourad Chloramphenicol agar. Controls were run parallely along with the test experiments to eliminate the errors. The medium being selective to yeast, helped to distinguish the desired organism from bacterial contaminants. The yeast colonies were then sub-cultured, purified and maintained on YPD agar medium. Twenty eight distinct yeast colonies were isolated from the rind and pulp of fresh and decayed Kokum and Jamun fruits. The isolates so obtained were preserved as glycerol stock and maintained at $-20^{\circ} \mathrm{C}$.

\section{Ethanol and Sugar Tolerance}

In fermented beverages production, such as wine, yeast cell consumes sugar and produces ethyl alcohol. In the initial fermentative phase yeast cells experience high sugar concentration $(20-24 \% \mathrm{~W} / \mathrm{V})$ while during production phase sugar concentration is reduced and ethanol starts accumulating $(8-14 \% \mathrm{v} / \mathrm{v})$. Yeast which can withstand to these stressors is considered as a suitable strain for wine production. Hence all the twenty eight isolates were subjected first to access their ethanol tolerance followed by their sugar tolerance of only the ethanol tolerant isolates.

A $5 \% \mathrm{v} / \mathrm{v}$ of each of the isolates (in its logarithmic phase) was inoculated into YPD broth containing $6-15 \% \mathrm{v} / \mathrm{v}$ ethanol concentration. The flasks/tubes were incubated at $30^{\circ} \mathrm{C}$ at $200 \mathrm{rpm}$ and $\mathrm{OD}$ was monitored upto $48 \mathrm{hrs}$. Most of the commercial ethanol production has ethanol concentration varying from $6-15 \%$ in the reactors and hence the similar range was used in our study to evaluate the ethanol tolerance among the twenty eight yeast isolates. Similar study of ethanol 
tolerance was evaluated of yeast isolated from grapes (Ali $\boldsymbol{e t}$ al., 2014; Lee $\boldsymbol{e t}$ al., 2011), Cashew apple juice (Osho A., 2005), apple and strawberry (Lee et al., 2011).

Except for the three isolates viz, FJ 10, JR 01 and KF 01, all the other isolates showed almost $75 \%$ reduction in growth after $48 \mathrm{hrs}$ at the minimum ethanol concentration of $6 \% \mathrm{v} / \mathrm{v}$ (Table 3). FJ 01, FJ 06, FJ 09, KF 02 showed a marginal growth $(20 \%)$ at $6 \% \mathrm{v} / \mathrm{v}$ ethanol concentration. Maximum growth was observed of $98 \%, 96 \%$ and $64 \%$ by the three isolates KF $01, \mathrm{FJ} 10$ and JR 01 respectively. Ethanol tolerance of the three most tolerant isolates at varying ethanol concentration is as shown in Figure 1 along with Saccharomyces cerevesiae (NCIM 3215) as a reference strain. FJ 10 and KF 01 showed significant ethanol tolerance up to $12 \%$ while a drastic decrease in the biomass is observed thereafter.

Ethanol tolerant yeasts also display the phenomenon of sugar tolerance (Gray, 1944). Sugar tolerance of the ethanol tolerant three isolates was evaluated by measuring the biomass (in terms of its optical density) of the isolates grown at varying sugar concentration. The study was performed by varying the sugar concentration up to $25 \% \mathrm{w} / \mathrm{v}$ as the maximum concentration. The maxima were as selected as the commercial wine production from must generally contains initial sugar concentration of $24 \% \mathrm{w} / \mathrm{v}$ (Salunkhe and Kadam, 1995). All the three isolates displayed similar pattern for sugar tolerance. Yeast with high sugar tolerance are capable to overcome the substrate inhibition leading into maximum growth and hence the product (Osho A., 2005)

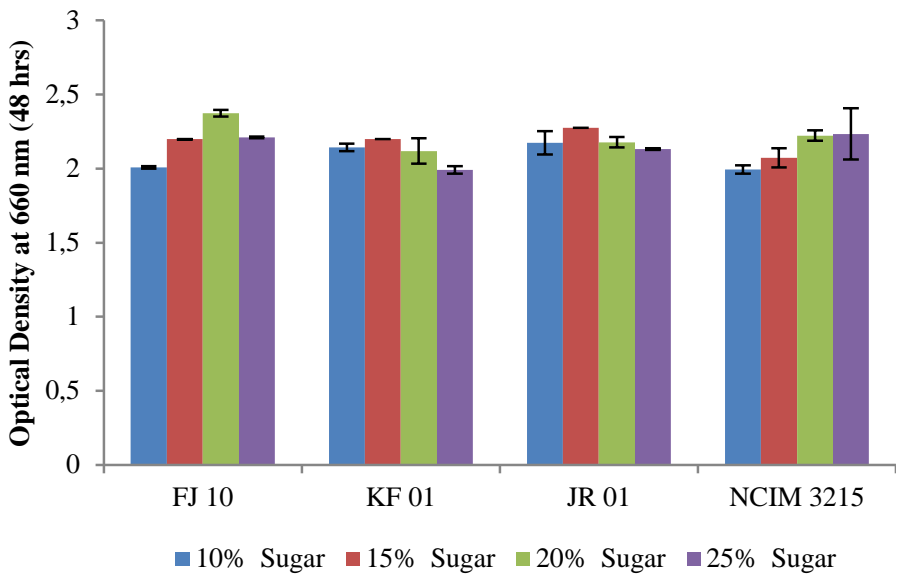

Figure 2 Sugar tolerances of isolates FJ 10, KF 01, JR 01, NCIM 3215

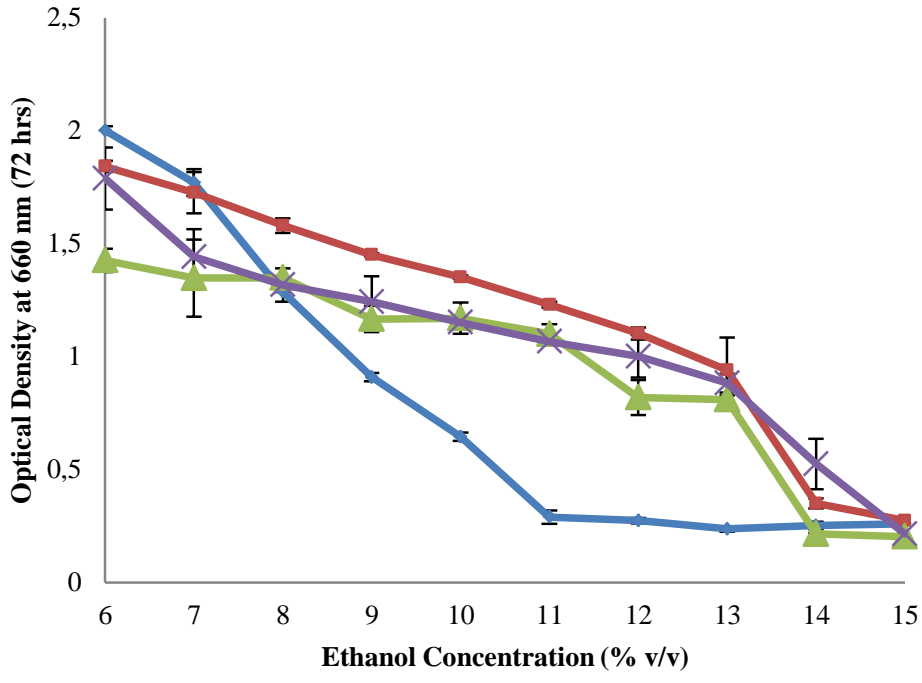

$\longrightarrow$ JR $01 \leadsto$ FJ $10 \leadsto$ KF $01 \leadsto$ NCIM 3215

Figure 1 Ethanol tolerance of isolates JR 01, FJ 10, KF 01 and reference strain Saccharomyces cerevisiae NCIM 3215

\section{Characterization of isolates}

Three ethanol and sugar tolerant yeast isolates JR 01, FJ 10 and KF 01 were then characterized on the basis of its morphological, biochemical and molecular traits. Table 4 enumerated below gives an overview of the morphological traits of all the three isolates.

FJ 10 and KF 01 displayed almost similar morphological traits except for their differences in appearance and bromocresol green uptake on Wallerstein Laboratory Nutrient (WLN) agar. JR 01 and KF 01 uptake the bromocresol green dye thereby changing the initial green colour of the medium to colourless. Thus both these isolates are capable of assimilating the dye without its metabolization. However, FJ 10 is unable to take up the dye and the medium colour is retained even after incubation of the isolate for six days. Bromocresol green dye is used in the selective isolation and identification of yeasts based on the color and morphological features of colony (Dennis et al.,2004, Ronald, M. A., 1946). Dennis et al., (2004) reported that yeast colonies take variety of shades of green on WLN media but not all strains have this ability. Our results are in agreement with Dennis et al. (2004).

Table 3 Percent reduction in growth of isolate and standard with respect to different alcohol concentration.

\begin{tabular}{|c|c|c|c|c|c|c|c|c|c|c|c|}
\hline \multirow{2}{*}{ Isolate } & \multirow{2}{*}{$\begin{array}{l}\text { OD without } \\
\text { alcohol } 72 \mathrm{hrs}\end{array}$} & \multicolumn{10}{|c|}{ Percent reduction } \\
\hline & & $6 \%$ & $7 \%$ & $8 \%$ & $9 \%$ & $10 \%$ & $11 \%$ & $12 \%$ & $13 \%$ & $14 \%$ & $15 \%$ \\
\hline FJ 10 & $2.217 \pm 0.064$ & 9.74 & 20.11 & 41.94 & 58.97 & 70.86 & 86.89 & 87.57 & 89.24 & 88.58 & 88.22 \\
\hline KF 01 & & 17.76 & 22.94 & 29.44 & 35.22 & 39.64 & 45.06 & 50.75 & 58.01 & 84.35 & 87.70 \\
\hline JR 01 & $2.198 \pm 0.101$ & 35.10 & 38.64 & 38.62 & 46.90 & 46.74 & 49.90 & 62.69 & 63.10 & 90.15 & 90.71 \\
\hline NCIM 3215 & $2.074 \pm 0.042$ & 13.74 & 30.47 & 36.47 & 40.04 & 44.45 & 48.52 & 51.71 & 57.40 & 74.63 & 89.58 \\
\hline
\end{tabular}

Table 4 Morphological parameters of ethanol-sugar tolerant

\begin{tabular}{|c|c|c|c|c|c|c|c|c|c|c|}
\hline ID & Fruit & Form & Elevation & Margin & Surface & Color & Appearance & Size & $\begin{array}{l}\text { Bromocresol } \\
\text { green uptake }\end{array}$ & $\begin{array}{l}\text { Gram } \\
\text { nature }\end{array}$ \\
\hline FJ 10 & Jamun & Circular & Umbonate & Entire & Smooth & Creamy white & Dull & Medium & No & Positive \\
\hline JR 01 & Jamun & Circular & Convex & Filiform & Smooth Hairy border & White & Dull & Small & Yes & Positive \\
\hline KF 01 & Kokum & Circular & Umbonate & Entire & Smooth & Creamy white & Slightly shiny & medium & Yes & positive \\
\hline
\end{tabular}

Biochemical characterization includes ability of three isolates towards assimilation and fermentation of different carbon and nitrogen sources (Bernette et al., 2000; Kurtzman\& Fell, 1998). Total of twenty two different sugars and three nitrogen sources were selected for the said study. Four sugars viz, glucose, sucrose, galactose and maltose were both assimilated and fermented by all the three isolates indicating them as the prolific carbon sources.

Thus it can be concluded out of fifteen sources five sources can acts as good energy as well as metabolic precursors.Molecular identification involved amplification of ITS region of the three isolates using the fungal ITS primers (White et al. 1990). The derived sequences were aligned by BLAST and sequence homology was used to identify the isolate. Based on the sequence identity FJ 10, KF 01 and JR 01 was identified as Saccharomyces sp.(98-99 \% ), Saccharomyces sp.(97-99 \%) and Candida tropicalis (98-100 \%) respectively.

The phylogenetic tree representing each isolates separately and all together is showed in Figure 3,4,5,6. Phylogenetic analysis details are showed in Table 6.
The optimal tree with the sum of branch length $=0.04030169,0.04556388$, 0.49273311 is shown for FJ 10, KF 01 and JR 01 respectively. The percentage of replicate trees with clustered texa is shown next to the branches (Felsenstein $\mathbf{J}$. 1985). There were a total of 677,531 and 407 positions in the final dataset of FJ 10, KF 01 and JR 01. The topology of the phylogenetic tree showed that FJ 10 and KF 01 shared a common branch point whereas along with JR - 01 they share common origin. 
Table 5 Biochemical properties of isolates

\begin{tabular}{|c|c|c|c|c|c|c|}
\hline \multirow{2}{*}{ Source } & \multicolumn{2}{|c|}{ FJ 10} & \multicolumn{2}{|c|}{ KF 01} & \multicolumn{2}{|c|}{ JR 01} \\
\hline & Fermentation & assimilation & Fermentation & assimilation & Fermentation & assimilation \\
\hline Arabinose & - & - & - & - & - & - \\
\hline Cellobiose & - & - & - & - & - & - \\
\hline Dextrose & + & + & + & + & - & + \\
\hline Galactose & - & + & - & + & - & + \\
\hline Inositol & - & - & - & - & - & - \\
\hline Inulin & - & - & - & - & - & - \\
\hline Lactose & - & - & - & - & - & - \\
\hline Maltose & + & + & + & + & - & + \\
\hline Mannitol & - & - & - & - & - & - \\
\hline Rhamnose & - & - & - & - & - & - \\
\hline Raffinose & - & - & - & + & - & - \\
\hline Sorbitol & - & - & - & - & - & - \\
\hline Sucrose & + & + & + & + & + & + \\
\hline Trehalose & - & - & + & + & + & + \\
\hline Xylose & - & - & - & - & - & - \\
\hline Nitrate & NA & - & NA & - & NA & - \\
\hline Nitrite & NA & - & NA & - & NA & - \\
\hline DAP & NA & + & NA & + & NA & + \\
\hline
\end{tabular}

Legend: +,- and NA means positive results, negative results and not applicable respectively. DAP

Diammonium Phosphate

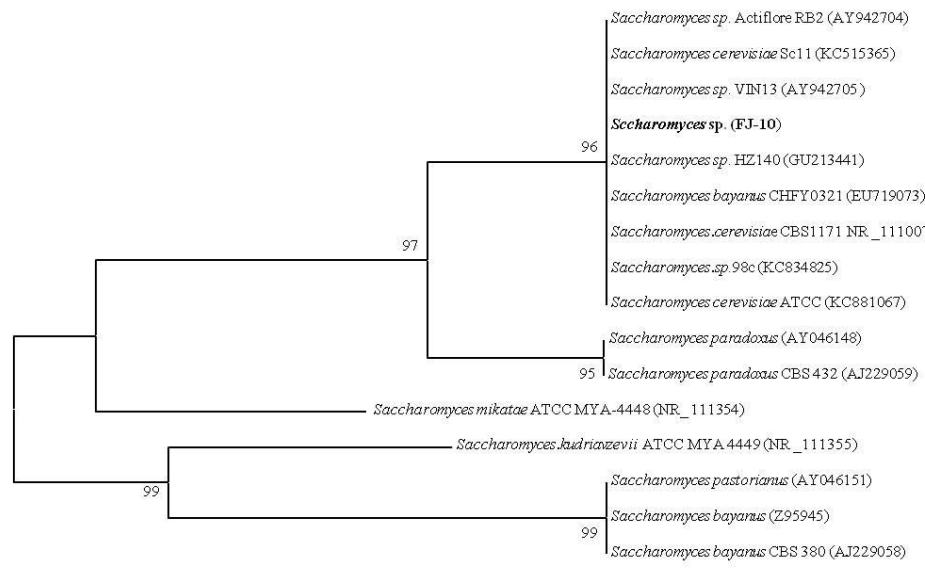

$\longmapsto 0.002$

Figure 3 Evolutionary relationship of FJ 10 isolate with its closest related species.
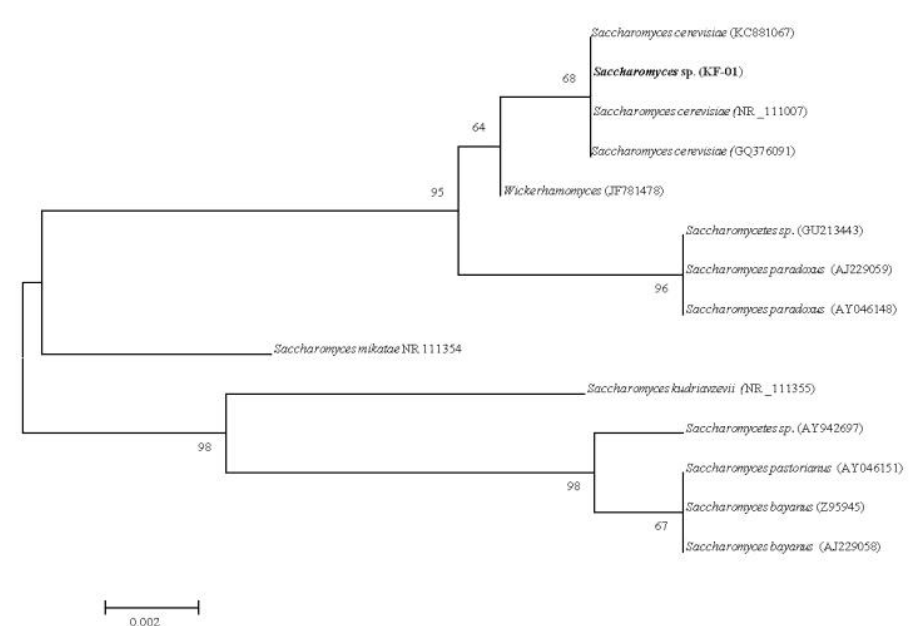

Figure 4 Evolutionary relationship of KF 01isolate with its closest related species.

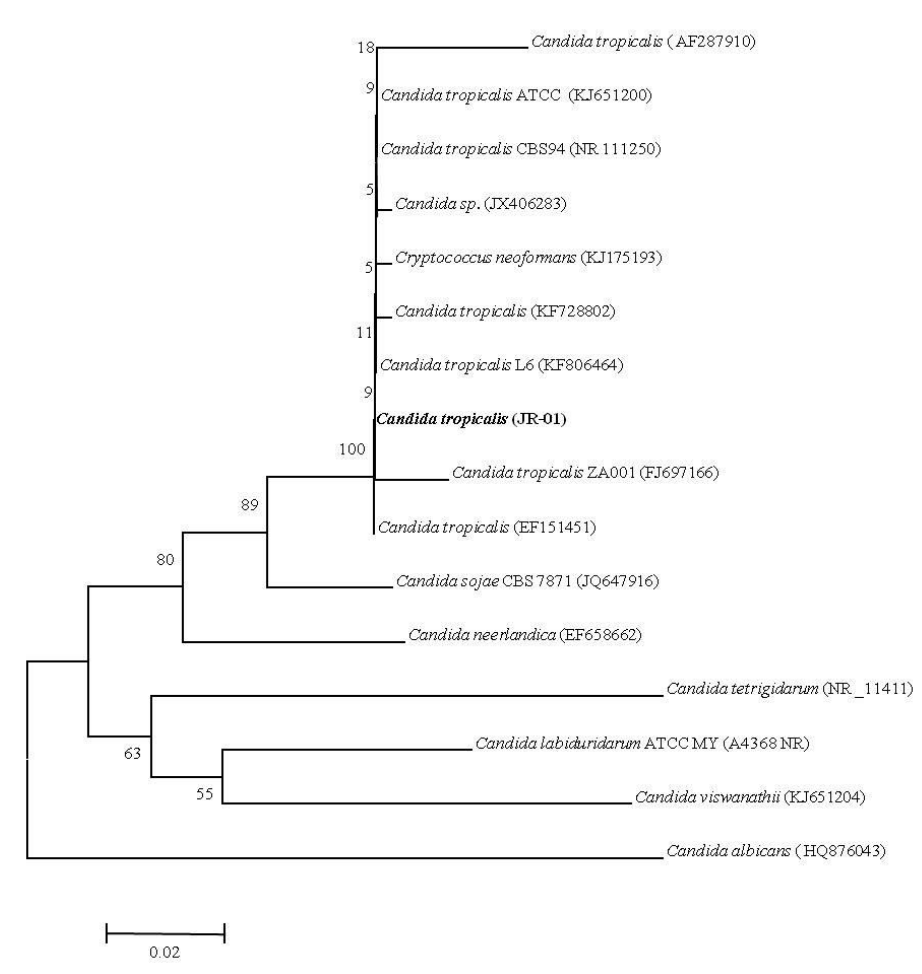

Figure 5 Evolutionary relationship of JR 01 isolate with its closest related species. 
Table 6 Phylogenetic analysis details of FJ 10, KF 01, JR 01.

\begin{tabular}{lccc}
\hline Parameters & FJ 10 & KF 01 & JR 01 \\
\hline Total number of sites for the analysis & 702 & 678 & 498 \\
\hline Percent similarity with type strain & $98-99 \%$ & $97-99 \%$ & $98-100 \%$ \\
\hline Conserved sites & 665 & 515 & 315 \\
\hline Variable site & 28 & 25 & 171 \\
\hline Parsimony informative sites & 20 & 17 & 72 \\
\hline Analysis & Phylogeny Reconstruction & Phylogeny Reconstruction & Phylogeny Reconstruction \\
\hline Statistical Method & Neighbor-joining & Neighbor-joining & Neighbor-joining \\
\hline Test of Phylogeny & Bootstrap & Bootstrap & Bootstrap \\
\hline No. of Bootstrap Replications & 1000 & 1000 & 1000 \\
\hline Substitution Model & Kimura 2-parameter model & Kimura 2-parameter model & Kimura 2-parameter model \\
\hline Substitutions to Include & Transitions + Transversions & Transitions + Transversions & Transitions + Transversions \\
\hline Rates among Sites & Gamma Distributed (G) & Gamma Distributed (G) & Gamma Distributed (G) \\
\hline Pattern among Lineages & Same (Homogeneous) & Same (Homogeneous) & Same (Homogeneous) \\
\hline Gaps/Missing Data Treatment & Complete deletion & Complete deletion & Complete deletion \\
\hline No. of Sites for actual analysis & 677 & 531 & 407 \\
\hline
\end{tabular}

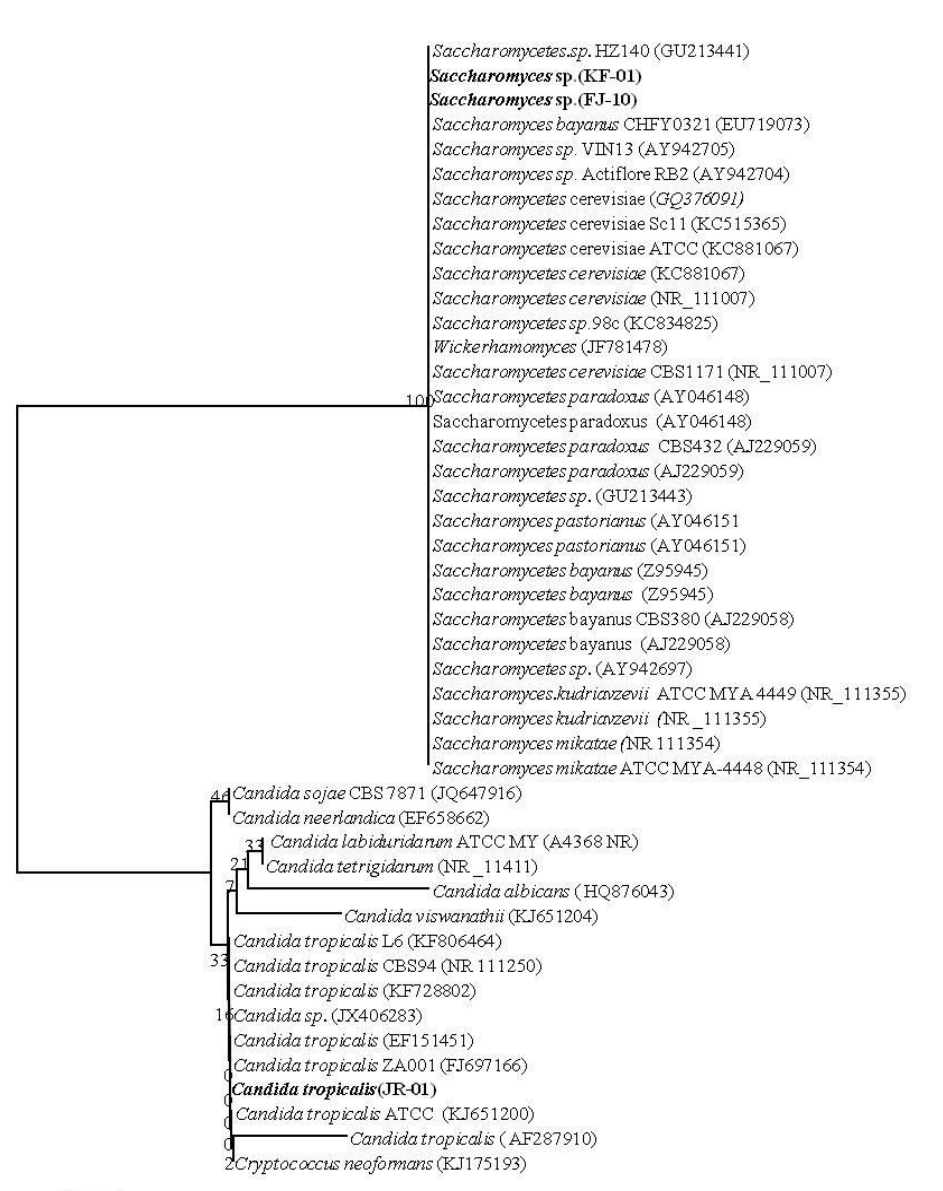

Figure 6 Phylogenetic tree representing FJ 10, KF 01 and JR 01 isolates together and their closest related species. The tree was constructed by the neighbor joining method with the Kimura two parameter distance method. Bootstrap values are indicative for 100 replicates.

\section{Microvinification}

All the twenty eight isolates were subjected to tolerance study. The aim of this strategy was to obtain only capable strains and to save time and resources needed for study. Microvinification results proved it. Both isolates shows promising results. All the wine analysis parameters like ethanol, residual sugar,titratable acidity, $\mathrm{pH}$, total anthocyanin's and per cent radical scavenging activity are satisfactory as compared to standard Saccharomyces cerevisiae NCIM 3215 starter culture. Isolate FJ 10 shows better results than standard strain used in this study (Table 7). Although Candida tropicalis is used for alcoholic fermentation from lignocellulosic wastes and (Sonali and Banwari 2007, Harinder et al., 2010, Latifa et al., 2007 ), there are no reports on its use as wine starter culture. Recently Candida tropicalis is considered as emerging pathogenic yeast (Kothavade et al., 2010). Therefore isolate Candida tropicalis JR 01 is rejected from further studies.

Table7 Microvinification results by yeast isolates and standard yeast

\begin{tabular}{lcccccc}
\hline Strain & $\begin{array}{c}\text { Ethanol } \\
(\% \mathrm{v} / \mathrm{v})\end{array}$ & $\begin{array}{c}\text { Residual sugar } \\
(\mathrm{g} / \mathrm{l})\end{array}$ & $\begin{array}{c}\text { Titratable } \\
\text { acidity }(\mathrm{g} / \mathrm{l})\end{array}$ & $\mathrm{pH}$ & $\begin{array}{c}\text { Total Anthocyanin } \\
(\mathrm{mg} / \mathrm{l})\end{array}$ & $\begin{array}{c}\text { \% radical } \\
\text { scavenging } \\
\text { Activity }\end{array}$ \\
\hline FJ 10 & $10.30 \pm 0.15$ & $3.13 \pm 0.2$ & $6.75 \pm 0.13$ & 3.47 & $420.24 \pm 0.27$ & $81.90 \pm 0.12$ \\
\hline KF 01 & $9.81 \pm 0.20$ & $3.94 \pm 0.17$ & $6.70 \pm 0.21$ & 3.45 & $419.37 \pm 0.14$ & $81.14 \pm 0.19$ \\
\hline NCIM 3215 & $10.15 \pm 0.12$ & $3.24 \pm 0.11$ & $6.80 \pm 0.26$ & 3.49 & $418.13 \pm 0.19$ & $80.56 \pm 0.09$ \\
\hline
\end{tabular}

\section{CONCLUSION}

Indigenous yeast flora isolated from Syzygium cumini and Garcinia indica belong to two genera Saccharomyces sp. (2) and Candida sp. (1) which is confirmed by ITS gene sequencing studies. Sequence alignment and phylogenetic study revealed close relatives of isolates in a cluster. Alcohol and sugar tolerance study of isolates gives promising results and it is also proved by microvinification study. Finally we conclude that Saccharomyces $s p$. (FJ 10 and KF 01) are suitable as wine starter cultures, especially for red wine. Further research is needed to find out the exact species. 


\section{REFERENCES}

A. KUMAR, R. ILAVARASAN, T. JAYACHANDRAN, M. DEECARAMAN, P. ARAVINDAN, N. PADMANABHAN AND M. R. V.KRISHAN. 2008. Antidiabetic activity of Syzygium cumini and its isolated compound against streptozotocin-induced diabetic rat. Journal of Medicinal Plants Research. 2(9), 246-249

ABE, N., MURATA, T. AND HIROTA, A. 1998.Novel DPPH radical scavengers, bisorbicillinol and demethltrichodimerol, from fungus.Biosci.Biotechnol.Biochem. 62(4), 661 666.http://dx.doi.org/10.1271/bbb.62.661

ALI MIR NAIMAN AND KHAN MOHAMMED MAZHARUDDIN. 2014 Screening, Identification and characterization of alcohol tolerant potential bioethanol producing yeasts. Current research in Microbiology and Biotechnology, 2(1), 316-324.

ALIA, S. S., KASOJUA, N., LUTHRAA, A., SINGHA, A., SHARANABASAVAA, H., SAHUA, A. 2008. Indian medicinal herbs as sources of antioxidants. Food Research International, 41, 1-15.

A.O.A.C. 2000.Official method 942.15 Acidity (Titratable) of fruit products with AOAC official method 920. 17th Edition, Washington, DC

ARUN CHANCHAICHAOVIVAT, PINTIP RUENWONGSA, BHINYO PANIJPAN. 2007. Screening and identification of yeast strains from fruits and vegetables: Potential for biological control of postharvest chilli anthracnose (Colletotrichum capsici). Biological Control 42, 326-335. http://dx.doi.org/10.1016/j.biocontrol.2007.05.016

ASISH G. R., UTPALA PARTHASARATHY, T.J. ZACHARIAH, P. GOBINATH, P.A. MATHEW, JOHNSON K. GEORGE AND K. V. SAJI. 2008 A comparative Estimation of (-) Hydroxycitric acid in Different Species of Garcinia. The Hort. J., 21(1), 26-29.

AYYANAR M, SUBASH-BABU P. 2012. Syzygium cumini (L.) Skeels: A review of its phytochemical constituents and traditional uses. Asian Pac J Trop Biomed, 2: 240-246.http://dx.doi.org/10.1016/S2221-1691(12)60050-1

BARNETT J. A., PAYNE R. AND YARROW D. 2000.Yeast, Characterization and Identification, $3^{\text {rd }}$ edn.Cambridge Uni. Press, Cambridge UK.ISBN-10 0521573963.

BRITO, F. A., LIMA, L. A., RAMOS, M. F., NAKAMURA M.J., CAVALHER MACHADOS S.C., SAMPAINO A.L. 2007.Pharmacological study of antiallergic activity of Syzygium cumini (L) Skeels., Brazillian Journal of Medical and Biological Research, 40, 105-115.

CHATTERJEE, A., YASMIN, T., BAGCHI, D., \& STOHS, S. J. 2003. The bactericidal effects of Lactobacillus acidophilus, garcinol and Protykin compared to clarithromycin, on Helicobacter pylori. Molecular \& Cellular Biochemistry, 243, 29-35

CHIRANJEEVI TIKKA, HARI PRASAD OSURU, NAVYA ATLURI, PRAVEEN CHAKRAVARTHI VEERA RAGHAVULU, NANDA KUMAR YELLAPU, ISMAIL SHAIK MANNUR, UPPU VENKATESWARA PRASAD, SUDHEER ALURU, NARASIMHA VARMA K AND MATCHA BHASKAR 2013. Isolation and characterization of ethanol tolerant yeast strains. Bioinformation, 9(8), 421-425.

CSOMA A., N. ZAKANY, A. CAPECE, P. ROMANO, M. SIPICZKI. 2010 Biological diversity of Saccharomyces yeasts of spontaneously fermenting wines in four wine regions: Comparative genotypic and phenotypic analysis International Journal of Food Microbiology, 140, 239 248.http://dx.doi.org/10.1016/j.ijfoodmicro.2010.03.024

DENNIS, E, B., CHRIS A. B., PETER A. B., AND ROGER S. 2004.Brewing. Science and Practice. Woodhead publishing limited and CRC press, England.498-499. eISBN 1855739062

E. NIKOLAOU, E. SOUFLEROS, E. BOULOUMPASI, N TZANETAKIS 2006. Selection of indigenous Saccharomyces cerevisiae strains according to their oenological characteristics and vinification results. Food Microbiology. 23, 205-211. http://dx.doi.org/10.1016/j.fm.2005.03.004

EBABHI A. M., ADEDOTUN ADEYINKA ADEKUNLE, WAHAB OLUWANISOLA OKUNOWO AND AKINNIYI ADEDIRAN OSUNTOKI.2013.Isolation and characterization of yeast strains from local food crops. Journal of yeast and fungal Research, 4(4), 38-43

FAGBEMI JOSEPHINE FERDINAND, UGOJI ESTHER, ADENIPEKUN TAYO, AND ADELOWOTAN OMOTOYIN. 2009 Evaluation of the antimicrobial properties of unripe banana (Musa sapientum L.), lemon grass (Cymbopogon citratus S.) and turmeric Curcuma longa L.) on pathogens African Journal of Biotechnology. 8 (7), 1176-1182.

FELSENSTEIN J. 1985. Confidence limits on phylogenies: An approach using the bootstrap. Evolution, 39, 783-791.http://dx.doi.org/10.2307/2408678

FREITAS A., MOLDÃO-MARTINS M., COSTA H.S., ALBUQUERQUE T.G., VALENTE A., SANCHES-SILVA A.2014.Effect of UV-C radiation on bioactive compounds of pineapple (Ananascomosus L. Merr.) byproducts.Journal of the Science of Food and Agriculture. 95(1), 44-52, http://dx.doi.org/10.1002/jsfa.6751

GHOSH SWAPAN KR. 2011.Study of yeast flora from fruit of Syzygium cumini (linn) skeel. Agriculture and Biology Journal of North America, 2(8), 1166 1170.http://dx.doi.org/10.5251/abjna.2011.2.8.1166.1170
GRAY W D. 1944. The sugar tolerance of four strains of distillers yeast.Bacteriology. 49, 445-452.

HARINDER SINGH OBEROIA, PRAVEEN V. VADLANI, KHUSHAL BRIJWANI, VINOD KUMAR BHARGAV, RAMABHAU TUMADU PATIL. 2010. Enhanced ethanol production via fermentation of rice straw with hydrolysate-adapted Candida tropicalis ATCC 13803. Process Biochemistry. 45(8), 1299-1306. http://dx.doi.org/10.1016/i.procbio.2010.04.017

HARJU S, FEDOSYUK H, PETERSON KR. 2004. Rapid isolation of yeast genomic DNA: Bust n' Grab. BMC biotechnology,4(8), 1 6.http://dx.doi.org/10.1186/1472-6750-4-8

J.M. CLEMENTE-JIMENEZ, L. MINGORANCE-CAZORLA, SERGIO MARTINEZ-RODRIGUEZ, FRANCISCO JAVIER LAS HERAS-VAZQUEZ, FELIPE RODRIGUEZ-VICO. 2004. Molecular characterization and oenological properties of wine yeasts isolated during spontaneous fermentation of six varieties of grape must. Food Microbiology, 21, 149-155. http://dx.doi.org/10.1016/S0740-0020(03)00063-7.

JENA, B. S., JAYAPRAKASHA, G. K., SINGH, R. P., \& SAKARIAH, K. K 2002.Chemistry and biochemistry of (-)-hydroxycitric acid from Garcinia. Journal of agricultural and food chemistry, 50(1), 10-22.

K. A. SHAH, M. B. PATEL, R. J. PATEL, AND P. K. PARMAR.2010.Mangifera indica (Mango). Pharmacognosy Review. 4(7), 42 48. http://dx.doi.org/10.4103/0973-7847.65325

K. P. SAMPATH KUMAR, DEBJIT BHOWMIK, S. DURAIVEL, M UMADEVI. 2012 Traditional and Medicinal Uses of Banana.Journal of Pharmacognosy and Phytochemistry. 1(3), 51-63.

KIMURA M. 1980. A simple method for estimating evolutionary rate of base substitutions through comparative studies of nucleotide sequences. Journal of Molecular Evolution, 16(2), 111-120.

KIRANA, H., \& SRINIVASAN, B. 2010. Aqueous extract of Garcinia indica choisy restores glutathione in type 2 diabetic rats. Journal of Young Pharmacists, 2, 265-268.

KONGSUWAN A. SUTHILUK P.THEPPAKORN T. SRILAONG V. AND SETHA S. 2009.Bioactive compounds and antioxidant capacities of phulae and nanglae pineapple.Asian Journal of Food and Agro-Industry.2, S44-S50.

KOTHAVADE, R. J., KURA, M. M., VALAND, A. G., PANTHAKI, M. H. 2010. Candida tropicalis: its prevalence, pathogenicity and increasing resistance to fluconazole. Journal of Medical Microbiology. 59(8), 873-880. http://dx.doi.org/10.1099/jmm.0.013227-0

KRISHNA K. L, PARIDHVI M., AND JAGRUTI A. PATEL. 2008. Review paper on nutritional, medicinal and pharmacological properties of papaya (Carica papaya Linn.). Natural Product Radiance, 7(4), 364-373

KURTZMAN, C. P. AND FELL, J. W. 1998.The Yeasts, a Taxonomic study, $4^{\text {th }}$ ed. Elsevier Science, Amsterdam.ISBN-10: 0444813128

LATIFA JAMAI, KHALIL ETTAYEBI, JAMAL EL YAMANI, MOHAMED ETTAYEBI. 2007. Production of ethanol from starch by free and immobilized Candida tropicalis in the presence of $\alpha$-amylase. Bioresource Technology. 98(14), 2765-2770. http://dx.doi.org/10.1016/j.biortech.2006.09.057

LEEYEON-JU YU-RI CHOI, SO-YOUNG LEE, JONG-TAE PARK, JAEHOON SHIM, KWAN-HWA PARK AND JUNG-WAN KIM. 2011. Screening wild yeast strains for alcohol fermentation from various fruits. Mycology, 39(1), 33-39. http://dx.doi.org/10.4489/MYCO.2011.39.1.033

LEE JUNGMIN. 2005. Determination of total monomeric Anthocyanin Pigment Content of fruit juices, Beverages, Natural Colorants, and Wines by the $\mathrm{PH}$ Differential Method: Collaborative Study. Journal of AOAC International. 88(5), 1269-1278

LEGRAS J.L, MERDINOGLU D, CORNUET J-M, KARST F. 2007. Bread, beer and wine: Saccharomyces cerevisiae diversity reflects human history. Molecular Ecology, 16(10),

2102. http://dx.doi.org/10.1111/j.1365-294X.2007.03266.x

LI, L. WANG, S. CHEN, J. XIE, J. WU, H. ZHAN, R. LI, W. 2014. Major antioxidants and in vitro antioxidant capacity of eleven mango (Mangifera indica L.) cultivars. International Journal of Food Properties. 17(8), 1872-1887. http://dx.doi.org/10.1080/10942912.2012.687798

M. S. BALIGA, HARSHITH P. BHAT, RAMAKRISHNA J. PAI, REKHA BOLOOR, PRINCY LOUIS PALATTY. 2011. The chemistry and medicinal uses of the underutilized Indian fruit tree Garcinia indica Choisy (kokum): A review. Food Research International, 44, 17901799.http://dx.doi.org/10.1016/j.foodres.2011.01.064

M.KALAISELVI, D.GOMATHI, C.UMA. 2012. Occurrence of Bioactive compounds in Ananus comosus (L.): A quality Standardization by HPTLC. Asian Pacific Journal of Tropical Biomedicine.2(3), S1341-S1346.

MILLER GAIL LORENZ. 1959. Use of Dinitrosalicylic Acid Reagent for Determination of Reducing Sugar. Analytical chemistry. 31(3), 426-428.

MONZON, R. B.; ADEBIYI, ADEBOWALE.1995.Traditional medicine in the treatment of parasitic diseases in the Philippines. Southeast Asian journal of tropical medicine and public health 26(3), 421-428.

MURUGANANDAN S., SRINIVASAN K., CHANDRA S., TANDAN S.K.LAL J. AND RAVIPRAKASH V. 2001. Anti-inflammatory activity of Syzygium cumini bark, Fitoterapia, 72(4), 369-375 
NICOLAI BERARDINI, RAMONA FEZER, JU“ RGEN CONRAD, UWE BEIFUSS, REINHOLD CARLE, AND ANDREAS SCHIEBER.2005.Screening of Mango (Mangifera indica L.) Cultivars for Their Contents of Flavonol O- and Xanthone C-Glycosides, Anthocyanins, and Pectin.Journal of Agricultural Food Chemistry. 53(5), 1563-1570.http://dx.doi.org/10.1021/if0484069

NICOLAI BERARDINI, ANDREAS SCHIEBER, IRIS KLAIBER, UWE BEIFUSS, REINHOLD CARLE, AND J"URGEN CONRAD. 2005. 7-OMethylcyanidin 3-O- $\beta$-D-Galactopyranoside, a Novel Anthocyanin from Mango (Mangifera indica L. cv. 'Tommy Atkins') Peels. Chem. Sci., 60 (7), 801-804.

OSHO A. 2005. Ethanol and sugar tolerance of wine yeasts isolated from fermenting cashew apple juice. African Journal of Biotechnology, 4(7), 660-662. P. CHAVAN, S. MANE, G. KULKARNI, S. SHAIKH, V. GHORMADE, D NERKAR, Y. SHOUCHE, M. DESHPANDE. 2009. Natural yeast flora of different varieties of grapes used for wine making in India. Food Microbiology, 26, 801-808. http://dx.doi.org/10.1016/j.fm.2009.05.005

PRAKASH O, KUMAR R, MISHRA A, GUPTA R. 2009. Artocarpus heterophyllus (Jackfruit): An overview. Phrmacognosy Review. 3(6), 353-358.

RAO R. S., BHADRA B. AND SHIVAJI S. 2008. Isolation and characterization of ethanol-producing yeasts from fruits and tree barks. Letters in Applied Microbiology, 47, 19-24.http://dx.doi.org/10.1111/j.1472-765X.2008.02380.x

REBELlO, L.P.G., RAMOS, A.M., PERTUZATTI, P.B., BARCIA, M.T. CASTILLO-MUÑOZ, N., HERMOSÍN-GUTIÉRREZ, I. 2014 Flour of banana (Musa AAA) peel as a source of antioxidant phenolic compounds. Food $\begin{array}{llll}\text { Research } & \text { International. } & \text { 397, } & \text {-403. }\end{array}$ http://dx.doi.org/10.1016/j.foodres.2013.11.039

RIVERA-PASTRANA, D.M., YAHIA, E.M. AND GONZÁLEZ-AGUILAR, G.A. 2010. Identification of phenolic and carotenoid compounds in carica papaya 1. 'Maradol' using liquid chromatography - mass spectrometry .Acta hort. (ISHS) 877:1197-1204

RONALD, M. A. 1946. Handbook of Media for Environmental Microbiology.CRC press, Floreda, USA.87p.ISBN 0849306035.

RUAN P.Z., ZHANG L.L. AND LIN M.Y. 2008.Evaluation of the antioxidant activity of Syzygium cumini leaves.Molecules, 13, 2545-2556.

SAITOU N. AND NEI M. 1987. The neighbor-joining method: A new method for reconstructing phylogenetic trees. Molecular Biology and Evolution, 4, 406425

SALUNKHE, D. K. AND KADAM S. S. 1995. Handbook of fruit Science and Technology: Production, composition, storage and processing. Marcel Dekker, Inc, New York.ISBN-0-8247-9643-8.

SELVI, A. T. JOSEPH, G. S., \& JAYAPRAKASHA, G. K. 2003.Inhibition of growth and aflatoxin production in Aspergillus flavus by Garcinia indica extract and its anti-oxidant activity.Food Microbiology, 20, 455-460.

SHARMA A. GUPTA P. VERMA A.K. 2013.Preliminary nutritional and biological potential of Artocarpus heterophyllus L. shell powder.Journal of Food Science and Technology. 50(4), 1-11. http://dx.doi.org/10.1007/s13197-013$\underline{1130-8}$

SHRIKANT BASLINGAPPA SWAMI, NAYAN SINGH J. THAKOR, MEGHATAI M. PATIL, PARAG M. HALDANKAR. 2012. Jamun (Syzygium cumini (L.)): A Review of Its Food and Medicinal Uses. Food and Nutrition Sciences, 3, 1100-1117. http://dx.doi.org/10.4236/fns.2012.38146

SONALI PATLE, BANWARI LAL. 2007. Ethanol production from hydrolysed agricultural wastes using mixed culture of Zymomonas mobilis and Candida

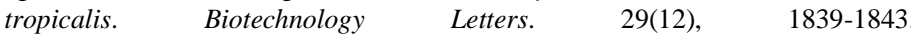
http://dx.doi.org/10.1007/s10529-007-9493-4

SPENCER JFT, AND SPENCER M. 1997. Yeast in Natural and Artificial Habitats. Springer-Verlag, Berlin, Heidelberg, 381p. ISBN-10: 0387568204

SRIDHAR, S. B. SHEETAL U. D. AND PAI M. R., 2005."Preclinical Evaluation of the Antidiabetic Effect of Eugenia jambolana Seed Powder in Streptozotocin-Diabetic Rats," Brazilian Journal of Medical and Biological Research, 38(3),463-468.http://dx.doi.org/10.1590/S0100-879X2005000300018

TAMURA K., DUDLEY J., NEI M., AND KUMAR S. 2007. MEGA4: Molecular Evolutionary Genetics Analysis (MEGA) software version 4.0. Molecular Biology and Evolution, 24(8), 15961599.http://dx.doi.org/10.1093/molbev/msm092

V. BENKOVIC, N. KOPJAR AND HORVAT. 2008. Evaluation of Radioprotective Effects of Propolis and Quercetin on Human White Blood Cells in Vitro. Biological and Pharmaceutical Bulltein, 31, 1778-1785. http://dx.doi.org/10.1248/bpb.31.1778

VARALAKSHMI, K. N., SANGEETHA, C. G., SHABEENA, A. N., SUNITHA, S. R., \& VAPIKA, J. 2010. Antimicrobial and cytotoxic effects of Garcinia indica fruit rind extract. American Eurasian Journal of Agricultural \& Environmental Sciences, 7, 652-656.

WHITE, T.J., T. BRUNS, S. LEE, AND J.W. TAYLOR. 1990. Amplification and direct sequencing of fungal ribosomalRNA genes for phylogenetics. Pp. 315322 In: PCR Protocols: A Guide to Methods and Applications, eds. Innis,M.A., D.H. Gelfand, J.J. Sninsky, and T.J. White. Academic Press, Inc., New York.ISBN-10: 0123721806

XU, J. W., IKEDA, K., \& YAMORI, Y. 2004. Upregulation of endothelial nitric oxide synthase by cyanidin-3-glucoside, a typical anthocyanin pigment.Hypertension, 44(2), 217-222.
Y. ZHAO, S. CHANG AND G. QU, 2009. Beta-Sitosterol Inhibits Cell Growth and Induces Apoptosis in SGC-7901 Human Stomach Cancer Cells, Journal of Agriculture and Food Chemistry. 57. 5211-5218. http://dx.doi.org/10.1021/jf803878n

YUE SUN, JINGJING GUO, FUBING LIU, YANLIN LIU. 2014. Identification of indigenous yeast flora isolated from the five wine grape varieties harvested in Xiangning, China. Antonie van Leeuwenhoek. 105, 533-540. http://dx.doi.org/10.1007/s10482-013-01050 